\title{
RESEARCH METHODOLOGY : TYPES IN THE NEW PERSPECTIVE
}

\author{
Firdaus $^{1}$, Zulfadilla $^{2}$, Fakhri Caniago ${ }^{3}$ \\ Universitas Muhammadiyah Sumatera Barat \\ firdaushisab@gmail.com,zulfadilla934@gmail.com
}

\begin{abstract}
Indonesian education requires every student to do research. Every time you carry out research, there are many methods in the manufacturing process which are commonly referred to as research methodologies, which are useful for distinguishing the types of research being carried out. There are several kinds of research methodologies including quantitative, qualitative, pure, applied, evaluation, descriptive, explanatory, experimental, non-experimental, ex post facto methodologies, surveys, case studies, and action research which have specific characteristics, weaknesses and strengths. By conducting literature studies and content analysis approaches, I got a new pattern in conducting research, namely combining two types of research, qualitative and quantitative, which were previously deemed impossible. What we have summarized in this article is for the development of Indonesia's educational civilization.
\end{abstract}

Keywords: Research Methods, New Perspective

\section{INTRODUCTION}

The methodology is generally defined as"a body of methods and rules followed in science or discipline". While the method itself is "a regular, systematic plan for or way of doing something". The word method is derived from the Greek methods (meta+bodos), which means way.1 So, the social research method is the systemic way that researchers use in the collection of data necessary in the process of identifying and explaining social phenomena that are being investigated. Dichotomy, in social sciences, are known two types of research methods namely quantitative and qualitative and many more research methods such as pure, applied, evaluation, descriptive, explanation, experimentation, non-experimental, ex post facto, survey, case study, and action research methods. ${ }^{1}$

And the methodology of this research is critical to be a reference of lecturers or students, especially students who are in research in the final semester. This method is the guideline for prospective scholars to float their research. One of the things students need to learn is to talk about this research method, and the focus of our discussion is the types of research. That's as much as we're trying to write as much as we can.

${ }^{1}$ Moh Nasir, Metode penelitian (Jakarta: Ghalia Indonesia, 1998), p. 31.

Manazhim : Jurnal Manajemen dan Ilmu Pendidkan

Volume 3, Nomor 1, Februari 2021; 1-16

https:// ejournal.stitpn.ac.id/index.php/manazhim 


\section{METHOD}

Discussion of methodology has been widely maintained that has a variety of types. The research methodology is a fundamental principle of research methods applied in the research process. The procedure is different from the way. Both terms are often used interchangeably because they have a similar meaning. A social scientist named Andrew Abbott. ${ }^{2}$. distinguish the definition of the two terms as follows: methodology is a fundamental principle, whereas method is the technique of application. This article will talk about research methodology, especially in social research. I use Andrew Abbott's proposed definition of social research methodology because it is easy to understand. As a basic principle, the discussion in this post will emphasize the necessary understandings and regulations of a method

\section{DISCUSSION}

\section{Quantitative and Qualitative Methods}

\section{Definition of quantitative and qualitative methods}

Quantitative and qualitative methods evolved primarily from the philosophical roots and social theories of the 20th century. The two research methods above have different paradigms theoretics, styles, and paradigmatic assumptions of research. Each contains strengths and limitations, has its research topics and issues, and uses different perspectives to look at social realities. ${ }^{3}$

Quantitative methods are rooted in traditional, positivistic, experimental or empiricist paradigms. This method evolved from the empirical thought traditions of Count, Mill, Durkheim, Newton and John Locke. "Quantitative research styles usually measure objective facts through concepts derived on variables and spelt out on indicators concerning aspects of reliability. Quantitative research is value-free and context-free, has many "cases" and subjects studied so that it can be displayed in the form of meaningful statistical data. The critical thing to note here is, the researcher is "separate" from the subject he studied. ${ }^{4}$

While the Weberian naturalistic-interpretative paradigm influences qualitative methods, the post-positivistic perspective of critical theory groups, as well as postmodernism as developed by Baudrillard, Lyotard and Derrida (Cresswell, 1994), the "style" of qualitative research, seeks to construct reality and understand its meaning. Thus, qualitative research is usually very attentive to processes, events and authenticity. Indeed in qualitative studies, the presence of researcher values is explicit in limited situations, involving subjects with relatively small numbers. As such, it is common for him to deal with thematic analysis. Qualitative researchers are usually

${ }^{2}$ Andrew Delano Abbott, Methods of discovery: heuristics for the social sciences (New York: W.W. Norton \& Co, 2004), p. 35.

${ }^{3}$ Ibid., p. 77.

${ }^{4}$ Ibid., p. 37. 
engaged in interactions with the realities they study.3 As explained earlier, and the research method also has paradigms assumptions. John W. Cresswell looked at several dimensions of paradigmatic beliefs that distinguish quantitative research from qualitative. These dimensions include ontological, epistemological, axiological, rhetorical, and methodological approaches. ${ }^{5}$

Ontologically, quantitative researchers view reality as "objective" and in glasses"out there", as well as independent of it. Meanwhile, investigators see truth as the result of reconstruction by individuals involved in social situations. Epistemologically, quantitative researchers are independent and keep a distance(detachment)with the fact studied. Qualitative researchers, meanwhile, have intense interactions with the points they look. Rhetorically or using language, quantitative research usually uses formal and impersonal research languages through numbers or statistical data. Thus, terminology or plural concepts are found in quantitative analysis, e.g."relationship" and"comparison"." dan" Meanwhile, qualitative research is often characterized by the use of informal and personal language such as"understanding", understanding discover"discover", and"meaning".". ${ }^{6}$

Methodically, quantitative research is attached to the use of deductive logic where theories and hypotheses are tested in causal logic. Static design is used through the determination of concepts, research variables and assumptions. Meanwhile, qualitative research prioritizes the use of inductive reasoning where categorization is born from a researcher's encounter with an informant in the field or the data found. So qualitative research characterizes information in the form of context bonds that will lead to patterns or theories that will explain social phenomena

Table 1. Quantitative and Qualitative Research "Style""

\begin{tabular}{|l|l|}
\hline Quantitative & Qualitative \\
\hline Measuring objective facts & $\begin{array}{l}\text { Constructing reality and cultural } \\
\text { significance }\end{array}$ \\
\hline Focus on variables & $\begin{array}{l}\text { Focus on processes and events } \\
\text { interactively }\end{array}$ \\
\hline Reliability is key & Authenticity is key \\
\hline Value-free & Explicit presence of values \\
\hline Free from context & Restricted situation \\
\hline Many cases and subjects & Few cases and subjects \\
\hline Statistical analysis & Thematic analysis \\
\hline Separate research & Research involved \\
\hline
\end{tabular}

${ }^{5}$ Judith Schoonenboom and R. Burke Johnson, 'How to Construct a Mixed Methods Research Design', KZfSS Kölner Zeitschrift für Soziologie und Sozialpsychologie, vol. 69, no. S2 (2017), p. 19.

${ }^{6}$ Peter Pruzan, Research methodology: the aims, practices and ethics of science (Cham: Springer, 2016), p. 23.

${ }^{7}$ Ranjit Kumar, Research methodology: a step-by-step guide for beginners, Fourth edition edition (Los Angeles: Sage, 2014), p. 79. 
Table 2. Paradigmical Assumptions of Quantitative and Qualitative Research ${ }^{8}$

\begin{tabular}{|c|c|c|c|}
\hline Assumption & Questions & Quantitative & Qualitative \\
\hline $\begin{array}{l}\text { Ontological } \\
\text { Assumptions }\end{array}$ & $\begin{array}{l}\text { What are the } \\
\text { basic } \\
\text { properties } \\
\text { Reality }\end{array}$ & $\begin{array}{l}\text { Reality is } \\
\text { objective and singular, } \\
\text { separate from the } \\
\text { researchers }\end{array}$ & $\begin{array}{l}\text { Subjective reality } \\
\text { and double as } \\
\text { visible to participants } \\
\text { in the study }\end{array}$ \\
\hline $\begin{array}{l}\text { Axiological } \\
\text { assumptions }\end{array}$ & $\begin{array}{l}\text { How } \\
\text { role of value? }\end{array}$ & $\begin{array}{l}\text { Value-free and } \\
\text { avoid bias }\end{array}$ & $\begin{array}{l}\text { Loaded with values } \\
\text { and biases }\end{array}$ \\
\hline $\begin{array}{l}\text { Rhetorical } \\
\text { assumptions }\end{array}$ & $\begin{array}{l}\text { How } \\
\text { use of } \\
\text { language } \\
\text { Research? }\end{array}$ & $\begin{array}{l}\text { - Formal } \\
\text { - By definition } \\
\text { - Impersonal } \\
\text { - Use } \\
\text { quantitative language }\end{array}$ & $\begin{array}{l}\text { - Informal } \\
\text { - Develop } \\
\text { decisions } \\
\text { - Personalized } \\
\text { - Use language } \\
\text { Qualitative }\end{array}$ \\
\hline $\begin{array}{l}\text { Assumption } \\
\text { Methodological }\end{array}$ & $\begin{array}{l}\text { What about } \\
\text { research } \\
\text { process? }\end{array}$ & $\begin{array}{l}\text { Deductive process } \\
\text { Causal consequences } \\
\text { Static design-category } \\
\text { limit before } \\
\text { Study } \\
\text { Context-free } \\
\text { Generalization leads } \\
\text { on predictions, } \\
\text { planation and } \\
\text { Understanding } \\
\text { Accuracy and reliability } \\
\text { through validity and } \\
\text { Reliability }\end{array}$ & $\begin{array}{l}\text { - Inductive process } \\
\text { - Factors are established } \\
\text { Simultaneously design } \\
\text { - Evolving rifing } \\
\text { categories Identified } \\
\text { during the research } \\
\text { process } \\
\text { - Context binding } \\
\text { - Patterns and theories } \\
\text { formed } \\
\text { for understanding } \\
\text { - Accuracy and } \\
\text { reliability } \\
\text { formed through } \\
\text { Verification }\end{array}$ \\
\hline
\end{tabular}

\section{Types, Orientations and Basic Principles of Qualitative Methods}

At least, five types of qualitative research methods are widely used, namely: (1)observation involved; (2) conversation analysis (3) discourse analysis; (4) content analysis; and (5) ethnographic data retrieval. Comments involved usually involve a qualitative researcher directly in a social setting. He observed, more or less "openly", in the various memberships of the roles of the subjects he studied. Conversational analysis generally focuses on conversations in an interaction. Researchers looked at the research of communicative competencies underlying daily social activities.

8 Ibid., p. 43.

${ }^{9}$ Ibid., p. 57. 
Discourse analysis is more interested in the use of language. Researchers, in this regard, have excellent attention to practice and contextuality. ${ }^{10}$

The analysis examines documents in the form of general categories of meaning. Researchers can analyze a wide variety of documents, from personal papers (letters, psychiatric reports) to a history of human interest (Gubrium et al., 1992: 1577). Ethnographic data retrieval is relatively unstructured. Content Researchers usually focus on extracting textures and flowing selective experiences from respondents through the process of interaction of researchers and subjects they research with "free" in-depth interview techniques (Gubrium et al., 1992: 1577). In sociology, ethnographic research began to develop in the late 1960s-1970s when survey methodology and philosophical basis. ${ }^{11}$

The driver was the target of criticism (Goldthorpe, 2000: 65). W. Lawrence Neuman tried to identify four factors related to orientation in the study using qualitative methods.

The first orientation is related to the approach used to the data. Qualitative methods treat data as intrinsically meaningful. Thus, the data in qualitative research is "soft", imperfect, imaginative, blurred superficiality, and a qualitative researcher will never be able to reveal everything entirely. Nevertheless, the data in qualitative research is empirical, consisting of documentation of various events, recordings of each speech, words and gestures of study objects, specific behaviours, written documents, and different visual images present in a social phenomenon (Neuman, 1997: 328).

The second orientation is the use of a non-positivistic perspective. Qualitative research widely uses interpretive and critical approaches to social issues. Qualitative researchers focus on subjective meanings, definitions, metaphors, and descriptions in specific cases (Neuman, 1997: 329). Qualitative researchers are trying to reach various aspects of the social world, including the atmosphere that forms an object that is difficult to capture through precise measurements or expressed in numbers. Thus, qualitative research is more metaphysical, including the goal of eliminating false beliefs formed in a study object. Qualitative research seeks to treat the study object not as an object, but more as a creative process and digest social life as something "deep" and boiling.

The third orientation is the use of research logic that is "logic in practice". Social research follows two forms of logic, namely reconstructed logic and logic in practice. Quantitative methods follow a reconstructed logic in which strategies are strictly organized, formalized and stimulated. While on qualitative methods, actual research is run irregularly, more ambiguously. They tied to specific cases. This, of course, reduces the ruling device and hangs itself on informal procedures built by the experiences in the field that the researcher discovered.

${ }^{10}$ Nana Syaodih Sukmadinata, Metode penelitian pendidikan (Bandung: Program Pascasarjana Universitas Pendidikan Indonesia dengan PT Remaja Rosdakarya, 2005), p. 77.

${ }^{11}$ Ibid 
The fourth orientation of the qualitative method is the taking of non-linear research measures. In quantitative methods, a researcher is usually faced with definitive research measures and remains with clear guidelines so that they are referred to as linear steps. Meanwhile, qualitative research methods make more room for the researcher to take non-linear and cyclical steps, sometimes causing "return" efforts on the research steps he has taken in the research process (Neuman, 1997: 330-331). This does not mean that the quality of research is low, but it is more about how to be able to exercise orientation in constructing meaning. ${ }^{12}$

Lincoln and Guba propose four essential things that reflect the qualitative paradigm when a researcher is about to submit his qualitative research proposal. First, the credibility that aims to demonstrate that the investigation conducted has aligned with scientific rules. This is to ensure accurate identification and description of research issues. Experiments and research must follow the laws of the game "credible to the constructors and the original multiple realities". Second, transferability concerns the ability to demonstrate the application of research findings in different contexts. Triangulation can be used as a reference to achieve the transferability of a qualitative study. Third, dependability where researchers seek to observe changes in conditions in social phenomena he studied as he adjusts the design of studies to filter out understanding of social settings. The latter is confirmability, which can be matched with objectivity. In this case, qualitative researchers are required to produce findings that can be confirmed by other parties (Marshall et al., 1989: 144-147). ${ }^{13}$

\section{Qualitative Methods in Practice}

Qualitative methods develop following proof as an unfinished process. It evolves from the process of searching and arresting meaning stipulated by reality and social phenomenon.4 A researcher involved in "conventional" qualitative research often undergoes the sell and trade process. This process can be understood in two symptoms. First, researchers engage interactively with subjects and play a role in shaping new realities. Likewise, fact interactively enriches a researcher's knowledge and social meaning. Second, researchers and "subjects" engage in the process of "exchange" so that interactions can run.

What often happens to qualitative researchers is the release of control to maintain his attitude and status when he jumps into the field. Positioning a qualitative researcher is one of the keys to success in obtaining accurate data. There is often an unequal relationship between the researcher and the reality he researches. Of course, this can result in bias from data being dug up even the interaction process takes place unnaturally and contains the structure of "bidden feudalism". For example, a researcher who has social status as an upper middle class wears spotless and neat clothes, speaks a formal language and demonstrates a "different" knowledge authority when researching smallholder farmers in the countryside. When the researcher's "social,

12 Ahmad Sabri, Meirison Meirison, and Jhoni Warmansyah, 'CONTINUITIES AND CHANGES', Epistemé: Jurnal Pengembangan Ilmu Keislaman, vol. 15, no. 1 (2020), pp. 23-38.

${ }^{13}$ Sukmadinata, Metode penelitian pendidikan, p. 33. 
economic, and cultural uniformity" forgets to be unearthed in the research process, there will be a sustained relationship legalized by the farmer's patron-client culture. ${ }^{14}$

For data in the field that related to the search, a qualitative researcher is required to collect existing data observantly. This is often difficult because not every research problem is interesting and significant; it is easy to search the data. Data in the field can be mapped into four domains: front stage-disclosed(FSD), back stage-disclosed (BSD), front stage enclosed (FSE), and back stage-enclosed (BSE). In the realm of FSD data, data is relatively easy to obtain and collect. In this realm of FSD data, qualitative researchers who are not very experienced can get information because all that is needed is data on the surface. For example, information data related to age and employment (except for specific jobs that are illegal/in violation of norms) can be easily obtained by a qualitative researcher. In the realm of BSD data, the difficulty level is already higher. In this realm, a qualitative researcher not only needs skills and research experience. But he was required to cultivate trust with the subjects he researched. Also, in the realm of BSD data, often, researchers need to triangulate to get accurate and authentic data. ${ }^{15}$

In the realm of FSE data, a qualitative researcher is often faced with ethical issues and his relationship with informants. In this context, there is often data that affects research but is closed. For example, when a qualitative researcher examines the issue of decision-making in the family, he is faced with the fact that a pregnant informant's child is out of wedlock. Of course, this can be asked of the informant because "objectively" this fact can be considered to have a relationship with how the informant made decisions within his family. ${ }^{16}$

The problem arises when the researcher tries to see the ethical dimensions in his question as well as its implications for the "proximity" of his relationship with the informant. The middle way that can be done is to keep the identity of the informant secret through a pseudonym, although this step will not necessarily eliminate the disruption of the next relationship between the researcher and the informant. The last data domain is BSE which is the most challenging domain of data to obtain. In this realm of data, a qualitative researcher takes extra time, expertise, experience, patience, perseverance to be able to reveal the reality he or she researches. Scandals of political relations, conspiracy, corruption, "taboo", are examples of social reality in this realm of data.

Qualitative methods, like other research methods, are fenced off with research ethics. It should be conveyed that in every study, both by using quantitative and qualitative research methods, a researcher is faced with two professional attitudes that must be inherent. The first attitude is sufficient knowledge to understand research techniques. The second attitude is sensitivity to the ethical aspects of

\footnotetext{
${ }^{14}$ C.R. Kothari, Research methodology methods \& techniques (New Delhi: New Age International (P) Ltd., 2004), p. 27, http://site.ebrary.com/id/10318734, accessed 28 Sep 2020.

${ }^{15}$ Kumar, Research methodology, p. 22.

16 ibid
} 
conducting research. The ethics of study have strong roots in social science as revealed in the value-free nature of experimentalism, neutrality from Weberian tradition to utilitarian ethics (Christians, "Ethics and Politics in Qualitative Research", $)^{17}$

In maintaining this second attitude, a qualitative researcher is often faced with a series of dilemmas. These dilemmas include the disguise of the informant's identity, confidentiality, involvement with deviants, relationships with power, and in the process. ${ }^{18}$

\section{Pure, Applied Research and Evaluation}

1. Pure/ basic and applied research

Reviewed from its purpose, qualitative research is distinguished into two kinds, namely basic research and applied research. Academic researchers in universities generally conduct basic research, so it is called academic or pure research. Pure research is a study that aims to understand a problem that leads to theoretical benefits, not on practical benefits. As for applied research is research that aims not only to understand the problem but to lead to the development of problem-solving with action for functional purposes. ${ }^{19}$

In determining the choice of the type of research to be used, researchers need to look at the level and ultimate purpose of the study. That basic research is generally a type of research that is widely done individually, especially in an academic environment, while research teams widely conduct applied research for practical purposes or the benefit of sponsors as bookers or holding funds. From these different research objectives, researchers can determine the design of the selected study based on the type of intent, so that the research strategies and objectives clearly and targeted (focus) can be set and reached. In scientific research methodology, there are known three levels of research, including exploratory, descriptive, and exploratory analysis. Experimental research, the first level of research that is exploring nature, has no known what is happening in the field of study. In this type of research (although the method is quantitative), research does not require a hypothesis, because the goal is to find various variables involved in a problem being examined. ${ }^{20}$

A further level of exploratory research or second-rate research is descriptive research. Suppose through exploratory research there can be a variety of variables involved in the target study, then in descriptive research. In that case, researchers can predict the variables involved concerning the relationship of the correlative level. Therefore, when using quantitative research methods at this descriptive state it already requires a hypothesis, and its data analysis techniques use statistical regression

\footnotetext{
${ }^{17}$ Schoonenboom and Johnson, 'How to Construct a Mixed Methods Research Design', p. 78

18 ibid

${ }^{19}$ Nasir, Metode penelitian, p. 27.

${ }^{20}$ Sukmadinata, Metode penelitian pendidikan, p. 99.
} 
analysis, path analysis, or linear structural relationship analysis, with correlation formulations. $^{21}$

At a further level of exploratory and descriptive research is a type of research called planation. The expansive research led his study to a causal analysis (causal relationship), as a further predictive strengthening of the proven significant correlation between the variables (independent-dependent), involved.

In quantitative research of this type of plantation, it is commonly used experimental forms that cover different types of designs from the simplest to the most complex, and the data analysis uses statistical analysis in the way of variant analysis (anava) or covariance analysis (anakova).

In qualitative research, this type of descriptive analysis is a general study used, especially in the course of social and humanities fields. This qualitative descriptive research method has the following characteristics: ${ }^{22}$

1. Able to describe processes over time in natural situations without the engineer of researchers, and can uncover a good relationship between researchers and informants.

2. It was enabling systematic documentation of the implementation of the program so that it can be used as a basis for the development of theory inductively (Muhadjir, 1996:109).

3. It is possible to perform inductive analysis oriented towards exploration, discovery and inductive logic, to find theories that are sourced on the patterns and real facts that occur.

4. It is possible to decrypt human behaviour in a natural context, i.e. the context of complete roundness, given that a phenomenon can only be meaningful in its entire context.

According to Sutopo (2002:141), the advanced state of descriptive research is applied research type (1) evaluation; (2) policies; and (3) development or action. The three types of research have different practical objectives. To understand the outline of the three, briefly explain the differences in goals and stages of implementation below. $^{23}$

\section{Evaluation Research}

Evaluation research is generally used to determine the effectiveness of achieving goals, results, or impacts of a program and policy implementation process that has been planned and implemented within a certain period. The results of the analysis in detail must be able to show the strengths and weaknesses of the program, to be able

${ }^{21}$ Schoonenboom and Johnson, 'How to Construct a Mixed Methods Research Design', p. 77.

22 Ibid

${ }^{23}$ Abbott, Methods of discovery, p. 79. 
to be delivered suggestions operationally in the form of actions to improve and develop the process of activities for a more later time. ${ }^{24}$

Based on the time of implementation and its objectives, evaluation research is distinguished into two kinds, namely formative evaluation research, and summative evaluation research. Formative evaluation research is conducted at the time the program is still running, to improve and develop its implementation further. In contrast, summative evaluation research is shown in the final period of the program implementation to determine the effectiveness of achieving the program's objectives as the final result of implementing a policy. According to Sutopo (2002:2), evaluation studies are research strategies that have the following characteristics. ${ }^{25}$

a. Able to capture the processes and meanings of each dynamic, occurring and evolving event.

b. The resulting formula is more comfortable to translate into policy actions.

c. The pressure is focused on a variety of data on quality with a depth of description, especially regarding the process and its meaning.

d. Through evaluation, studies can be presented a detailed description of the implementation of a program.

e. Can be presented descriptions of various participants and different roles.

f. A description of how the program affects the goal can be presented.

g. It can be described observable changes regarding the results and their impact.

h. Can be described analysis of the strengths and weaknesses of a program.

In its application, evaluation research can use a mindset-based approach and analysis that is related to the underlying variables involved. Evaluation research aims to excavate, discover, and understand a wide range of information both the strengths and weaknesses of all variables involved in the program, from a particular work (e.g. buildings, artwork, communication media, etc., and further attempted to develop suggestions for further development. ${ }^{26}$

In evaluation, studies can use specific approach models that are viewed most appropriately, in each case reviewed (Patton, 1986:51). These approach models include the critique model, the Context, Input, Process, Product (CIPP) models- which are widely used in education--, and the Strengths Weaknesses, Opportunities, Threats (SWOT) analysis models. ${ }^{27}$

\footnotetext{
${ }^{24}$ Sukmadinata, Metode penelitian pendidikan, p. 11.

${ }^{25}$ Kumar, Research methodology, p. 55.

${ }^{26}$ Schoonenboom and Johnson, 'How to Construct a Mixed Methods Research Design', p. 45.

27 ibit
} 


\section{Descriptive research and expansiveness}

Descriptive research is conducted to provide a more detailed picture of a symptom or phenomenon. The final results of this study are usually typology or patterns regarding the wonder that is being discussed. ${ }^{28}$

This researcher could also be said to be a continuation of the exploratory research. Exploratory research has provided a basic idea so that this research reveals in more detail. This research is synonymous with research that uses the question "HOW" in developing existing information. The objectives of the descriptive study are:

A. describes the mechanism of a process;

B. create a set of categories or patterns.

Extensive research is a study that examines the causal association between 2 or more phenomena. This comprehensive research is used to determine whether a causal relationship is genuine or not, to determine the truth between 2 or more competing planets.

The purpose of the comprehensive research could also be to explain, for example, "why" a particular type of city has a higher level of well-being than other types of cities. Description: in the descriptive research it is only explained that the level of well-being in the town of that type is not the same as other types of cities, but it is not defined "why" the relationship of cause and effect can occur. ${ }^{29}$

\section{Experimental Or Non-Experimental Research}

In the field of education, the experimental research method is a research method used to know the effect of a particular action or treatment that is intentionally carried out on one specific condition. In other words, use experimental methods in educational research by answering what happens when something is done under certain carefully controlled conditions. In this relationship, the study manipulates a stimulus in the form of treatment or experimental conditions, then observes the influence or changes caused by deliberate therapy or manipulation. To influence or change clean or avoid things that can interfere with the event of such changes, then the research conducts careful control over the possible influx of other factors. ${ }^{30}$

Broadly non-experimental research can be interpreted as a method of solving problems in research or determining the correlation between variables by making observational observations of research subjects with conditions as they are without any intervention from researchers. Non-experimental research can

\footnotetext{
${ }^{28}$ Kumar, Research methodology, p. 11.

${ }^{29}$ Kothari, Research methodology methods \& techniques, p. 12.

${ }^{30}$ Sanjaya, Vienna. 2013. Education Research. Jakarta; Kencana
} 
describe the actual requirement of a research subject. In this case, the intervention cannot be passed because the research subject during the study is not in a location, so only other variables are not taken into account. ${ }^{31}$

\section{Expos facto Research, Survey, Case Study, Action Research}

\section{Ex post-Facto}

The definition of ex post facto is after the fact, i.e. research conducted after an event occurs. Ex post facto research aims to find causes that allow changes in behaviour, symptoms or phenomena caused by an event, behaviour, sign or phenomenon caused by an event, action or things that cause changes in free variables as a whole already occur. For example, the influence of alcohol circulation on youth delinquency levels. In this case, the researcher is unlikely to conduct experiments because he is unlikely to manipulate the condition of the subject (making the grocery store vendors sell liquor) then measure the level of juvenile delinquency. However, these influences can be tested by comparing youth delinquency rates in areas where liquor circulation is restricted to areas where alcohol circulation is exempt. ${ }^{32}$

\section{Ex Post Facto Assortment}

Ex post facto research can be distinguished into two types, namely:

1. Causal research is a study that involves data collection measures to determine whether there are a relationship and the level of relationship between two or more variables. Correlation research has three essential characteristics for researchers who want to use it, namely: (a) Correlation research is appropriate if complex variables and research is unlikely to manipulate and control variables as in experimental studies; (b) Allows variables to be measured intensively in real (environmental) settings, and (c) Allows researchers to obtain significant degrees of association.

2. Causal comparative research (comparative causal analysis) is a basic comparative causal approach involving the activities of researchers that begins by identifying the influence of one variable on another variable. Then he seeks to find the possible variable cause. Or in other words in the comparative causal research researchers are trying to look at the research question of what is the effect of $X$ ? For example, what effect does it have, if a child without attending kindergarten school, then goes straight to first grade in elementary school? In the case of education, what happens when a firstyear student who comes from high school, without going through

31 Tus Sadiah, Halimah, et al. 2019. Pharmaceutical Computer Applications. Jakarta; University Research and Community Service Institute.

32 Widarto. 2013. Ex Post Facto Research. Yogyakarta; University of California, Berkeley. 
matriculation lectures directly take engineering courses, as well as students from vocational school?

\section{Ex Post Facto Research Characteristics}

1. Data is collected after all events occur.

2. Bound variables are determined first, then run back to find their cause, relationship, and meaning.

3. Descriptive research explains its findings as observed.

4. Correlational research is trying to find causal relationships of the phenomenon studied.

5. Experimental research, and ex post facto basic logic used and the goal that wants to be achieved equally in determining empirical validity. Example: if $\mathrm{x}$ then $\mathrm{y}$. The difference between experimental research and ex post facto is that there is no direct control of free variables in ex post facto analysis.

Ex post facto research is conducted if in some ways, and experimental research cannot be carried out. These are:

a. If it is not possible to select, control, and manipulate the factors necessary to examine the causal relationship directly.

b. If the control of all variables is unrealistic and artificial, it means difficulty preventing regular interaction with other affecting variables.

c. If controls are laboratories for some purpose, it is impractical, both in terms of cost and ethics.

\section{Advantages of Ex Post Facto Research}

1. Suitable for circumstances that cannot be done with experimental research.

2. Information about the nature of what phenomena occur, by what they appear, under what conditions the phenomenon occurs. In the sequence and patterns of what the phenomenon occurs.

3. Advances in statistical engineering make expost facto design more enduring.

\section{Ex Post Facto Research Weaknesses}

1. Less control over free variables

2. It is difficult to ascertain whether causative factors have been included and identified.

3. No single factor causes a consequence, but some combinations and interactions of factors run together under certain conditions resulting in certain products. 
4. A phenomenon may not only be the result of many causes but also from one reason in one way and from another.

5. If a relationship between two variables is found, it is difficult to see which causes and which are the consequences.

6. The fact that two or more factors are related does not necessarily indicate a causal relationship. All elements may be associated with an additional feature that is unknown or not observed.

7. Classifying subjects into dichotomy groups (e.g. the accomplished and the underachieving) for comparison purposes is fraught with problems since categories like these are vague, can vary, and are temporary.

8. Comparative research in natural situations does not provide a controlled selection of subjects. It's hard to put the same group of residents in everything except their exposure to a single variable.

It is a method of research done by looking back at the events that have occurred to know the cause of the event. This method does not use or manipulate variables(probable) that may occur

Examples:

Research conducted to uncover riots and demonstrations

\section{Survey}

This research is a study that uses questionnaires as research instruments. A questionnaire is a sheet containing several questions with a standard structure. In the conduct of the survey, the condition of the study was not manipulated by researchers.

\section{Case Study}

According to Sutopo (2002:136), taking into account some of the limitations of qualitative research, it is understandable that in fact, qualitative research is a case study, namely analysis that is tied to its context. That is, all case study designs in qualitative research are always contextual, namely research that bases its study on the nature of specificity, and there is absolutely no thought attempt to generalize the conclusiveness of the course. According to Yin, in conducting case study research, researchers can interact continuously with the theoretical issues studied and with the data collected. Also, it can use various sources of research evidence about real-life conflicting events. The researchers of this case study pointed to detailed descriptions of the conditions in a context, about what actually happened in the field of study, given that this type of case study research attaches great importance to the description of the process of what, why and how something happened, to lead to an understanding of the meaning of a reviewed phenomenon. 


\section{Action research}

According to Kemmis in his book The Action Research Reader (1997), PT was first introduced by Lewin in England in 1933. This method developed steadily and spread throughout the world and was known in Australia only around the 1970s.

For the field of education, Sukamto (1996) explained that action research is a group of activities in the development of curriculum, staff, schools, systems and policies. These activities have similarities in terms of identifying strategies of a planned action that are then implemented, and systematically observed, reflected and modified. Participants who are also clients in total are involved in all such activities. In 1994, Calhoun explained that Action Research was an effort to improve the quality of the organization and its ${ }^{33}$ appearance. Experts Summarizing opinions of, Badrun KW (1998) explains: Action Research (AR) or Action Research (PT) is research conducted collaboratively by participants in social sciences and education to improve the understanding and implementation of its own work, and also have an impact on the surrounding environment. In this case, PT can be used in the world of education, tubs inside and outside the classroom. It's a little different from Classroom Action Research (CAR) or Class Action Research (PTK) which specializes more in-class research and should be done by teachers. This is following Hopkins opinion which says PTK is research actions taken by teachers to improve and or develop the way teachers teach. ${ }^{34}$

\section{CONCLUSION}

Such social research then becomes exciting and complicated, especially if researchers are not imprisoned by merely focusing on the relationship between variables, and also not just the focus of the relationship between an independent variable and dependent variable. But more than that, researchers interpreted variable anatomy in depth through previous research studies that were conceptualized to a specific population called construct theoretical. Construct theoretical variables basically contain contextual, conceptual definitions, dimensions and indicators as signs or traits of the variable itself, which by the research methodology is called an exogenous variable. It is through this theoretical construct that the nature of the relationship between variables is interpreted more. Similarly, the relationship between the independent variable and the dependent variable is not only defined as connecting a series of scores from an independent variable with a series of dependent variable scores. But the relationship between independent variables and dependent variables should be defined by the empirical

\footnotetext{
${ }^{33}$ Sukmadinata, Metode penelitian pendidikan, p. 77.

34 Kartowagiran, Badrun. 2005. Basic Basic Research Actions. Yogyakarta; University of California, Berkeley.
} 
tendencies or conditions of each of them. The meaning of variable trends is empirical facts in the population based on the data in the research sample. Because of the complexity in the process of exploration of each research variable, a qualitative research approach is needed through content analysis as part of a qualitative research method also called exploratory research. This concept underlies the need for a new paradigm research method called neuro research method. Neuro research itself is a term that seeks to describe the interconnected and complex investigation that is not only through qualitative-quantitative research methods often called mixed-methods. But more so through "qualitative-quantitative-qualitative" research that this pattern is then called Neuro research. This difference is another alternative in addition to the mixed-methods that have developed over the years.

\section{REFERENCES}

Abbott, Andrew Delano, Methods of discovery: heuristics for the social sciences, New York: W.W. Norton \& Co, 2004.

Kothari, C.R., Research methodology methods \& techniques, New Delhi: New Age International (P) Ltd., 2004, http://site.ebrary.com/id/10318734, accessed 28 Sep 2020.

Kumar, Ranjit, Research methodology: a step-by-step guide for beginners, Fourth edition edition, Los Angeles: Sage, 2014.

Nasir, Moh, Metode penelitian, Jakarta: Ghalia Indonesia, 1998.

Pruzan, Peter, Research methodology: the aims, practices and ethics of science, Cham: Springer, 2016.

Sabri, Ahmad, Meirison Meirison, and Jhoni Warmansyah, 'CONTINUITIES AND CHANGES', Epistemé: Jurnal Pengembangan Ilmu Keislaman, vol. 15, no. 1, 2020, pp. 23-38 [https://doi.org/10.21274/epis.2020.15.1.23-38].

Schoonenboom, Judith and R. Burke Johnson, 'How to Construct a Mixed Methods Research Design', KZfSS Kölner Zeitschrift für Soziologie und Sozialpsychologie, vol. 69, no. S2, 2017, pp. 107-31 [https://doi.org/10.1007/s11577-0170454-1].

Sukmadinata, Nana Syaodih, Metode penelitian pendidikan, Bandung: Program Pascasarjana Universitas Pendidikan Indonesia dengan PT Remaja Rosdakarya, 2005. 